\title{
Site-specific binding of quinones to proteins through thiol addition and addition-elimination reactions
}

\author{
Wen-Wu Li, Jürgen Heinze and Wolfgang Haehnel \\ Supporting Information
}

\section{Experimental Materials and Methods.}

\section{General}

2,3-dimethoxy-5-methyl-1,4-benzoquinone (UQ-0), 2-methyl-1,4-naphthoquinone (MQ-0), 2,3,5trimethylhydroquinone, yeast iso- 1 cytochrome $c$ and all other chemicals of the highest available grade were obtained from Aldrich / Sigma. ${ }^{1} \mathrm{HNMR}$ data were recorded on a Bruker 250 or $400 \mathrm{MHz}$ spectrometer.

\section{Reverse Phase HPLC.}

Analytical reverse phase HPLC was carried out on a Waters model 600E system equipped with a Waters model 996 photodiode array detector. A $4.8 \times 100 \mathrm{~mm}$ stainless steel column packed with PerSeptive was run at a flow rate of $1 \mathrm{~mL} / \mathrm{min}$. Preparative HPLC was performed on a Waters DeltaPak C18 PrePak column $(40 \times 300 \mathrm{~mm}, 15 \mu \mathrm{m})$ at a flow rate of $50 \mathrm{~mL} / \mathrm{min}$. Semi-preparative HPLC was performed on a YMC-Pack ODS column $(250 \times 20 \mathrm{~mm}, 15 \mu \mathrm{m})$ at a flow rate of $10 \mathrm{~mL} /$ min. Solvents of $0.1 \%$ TFA (A) and 4/1 acetonitrile/water plus $0.1 \%$ TFA (B) were used. A gradient of $20 \% \mathrm{~B}$ to $80 \% \mathrm{~B}(\mathrm{~A}+\mathrm{B}$ ) over 31 min was used for HPLC analysis of the coupling reactions between quinones and thioether quinone adducts with yeast iso- 1 cyt $c$ at $\mathrm{pH} 4$ and 7.5.

\section{Mass spectrometry.}

Electron impact (EI) mass spectra were recorded by a Finnigan MAT 445 apparatus (EI, $70 \mathrm{eV}$ ). Electrospray ionization (ESI) mass spectra were recorded on a Finnigan model TSQ 700 tandem quadrupole mass spectrometer with an eletrospray interface. Matrix assisted laser desorption ionization time of flight mass spectra were performed using a Voyager DE-Pro (Perspective Biosystems, Framingham, MA) time-of flight instrument. All spectra have been obtained both in linear and reflection mode and in positive ion mode. The accelerating voltage was $20 \mathrm{kV}$, and the grid voltage $75 \%$, and the guide wire voltage $0.02 \%$. Peptides were dissolved in $10 \mu \mathrm{L}$ of $50 \% \mathrm{CH}_{3} \mathrm{CN}$ with $0.1 \%$ TFA for ESI-MS, and $1 \mu \mathrm{L}$ of this solution mixed with $2 \mu \mathrm{L}$ matrix solution containing 10 $\mu \mathrm{g} / \mu \mathrm{L}$ of $\alpha$-cyano-4-hydroxycinnamic acid have been loaded on a stailess steel plate, then dried for MALDI and post source decay (PSD)-MALDI MS analysis. All data were calibrated using an external calibration standard mixture of angiotensin I, ACTH and insulin (bovine).

\section{Synthesis of model thioether quinone conjugates.}

2,3,5-trimethyl-1,4-benzoquinone (TMBQ) were synthesized by the oxidation of 2,3,5trimethylhydroquinone with potassium dichromate $\left(\mathrm{K}_{2} \mathrm{Cr}_{2} \mathrm{O}_{7}\right)$ in HOAc as described. ${ }^{20}$ The synthesis of UQ-0, MQ-0, and TMBQ with $N$-acetyl L-cysteine [(N-Ac)Cys] and/or 2-mercapthoethanol conjugates were performed in ethanol or a mixture of ethanol and water at room temperature. ${ }^{12}$ They were further purified by preparative HPLC and lyophilized. The purity of these conjugates was greater than $98 \%$ as determined by analytical HPLC.

N-Acetyl-S-(2, 3-dimethoxy-5-methyl-1, 4-benzylquinonyl-6)cysteine, UQ-(N-Ac)Cys. To a solution of of UQ-0 (182 mg, $1.0 \mathrm{mmol})$ in $4 \mathrm{~mL}$ of ethanol and $1 \mathrm{~mL}$ of water was added $\mathrm{N}$-acetyl Lcysteine $(81.5 \mathrm{mg}, 0.5 \mathrm{mmol})$. The solution was stirred overnight. The reaction mixture was diluted 
with $20 \mathrm{~mL}$ of water, extracted with $2 \times 20 \mathrm{~mL}$ of EtOAc, and then evaporated the solvent. Preparative HPLC was used for purification and yielded UQ-(N-Ac)Cys as a red solid (50 mg, yield $29 \%$ ). ESIMS m/z: $344[\mathrm{M}+\mathrm{H}]^{+}, 366[\mathrm{M}+\mathrm{Na}]^{+}, 709$ [2M+Na] $]^{+}$EI-MS m/z (\%): 343.2 (4.4), 284.1 (6.6), 227.1 (76.1), 216.1 (100), 214.0 (44.4), 201.1 (20.2), 199.1 (11.8), 183.1 (15.0), 181.0 (11.4). ${ }^{1} \mathrm{H}-\mathrm{NMR}$ $\left(\mathrm{CD}_{3} \mathrm{COCD}_{3}\right) \delta: 7.40(1 \mathrm{H}, \mathrm{d}, \mathrm{NH}), 4.60(1 \mathrm{H}, \mathrm{m}, \mathrm{H}-\alpha), 3.88\left(6 \mathrm{H}, \mathrm{s}, 2 \times \mathrm{OCH}_{3}\right), 3.52(1 \mathrm{H}, \mathrm{dd}, \mathrm{H} 1-\beta)$, 3.28 (1H, dd, H2- $\beta$ ), 2.05 (3H, s, $\left.\mathrm{CH}_{3}\right), 1.82$ (3H, s, $\left.\mathrm{CH}_{3} \mathrm{CO}\right) .{ }^{1} \mathrm{H}-\mathrm{NMR}(90 \% 20 \mathrm{mM}$ Tris-HCl, $\mathrm{pH}$ $\left.7.5 / 10 \% \mathrm{D}_{2} \mathrm{O}\right) \delta: 8.10(1 \mathrm{H}, \mathrm{d}, \mathrm{NH}), 4.31(1 \mathrm{H}, \mathrm{m}, \mathrm{H}-\alpha), 3.88\left(6 \mathrm{H}, \mathrm{s}, 2 \times \mathrm{OCH}_{3}\right), 3.47(1 \mathrm{H}, \mathrm{dd}, \mathrm{H} 1-\beta)$, 3.19 (1H, dd, H2- $\beta$ ), 2.06 (3H, s, $\mathrm{CH}_{3}$ ), 1.89 (3H, s, $\mathrm{CH}_{3} \mathrm{CO}$ ).

S-(2, 3-dimethoxy-5-methyl-1, 4-benzylquinonyl-6)-2-mercaptoethanol, UQ- $\mathrm{S}\left(\mathrm{CH}_{2}\right)_{2} \mathrm{OH}$. Tо а solution of of UQ-0 (54 mg, $0.3 \mathrm{mmol})$ in $1.5 \mathrm{~mL}$ of ethanol was added 2-mercaptoethanol $(10 \mu \mathrm{L}$, $0.14 \mathrm{mmol}$ ). The solution was stirred overnight. The reaction mixture was directly purified by preparative HPLC to yield UQ-S( $\left.\mathrm{CH}_{2}\right)_{2} \mathrm{OH}$ as a red oil (8 mg, yield $\left.22 \%\right)$. EI-MS m/z (\%) : 260.0 (21.6), 258.0 (66.1), 243.0 (33.1), 242.0 (96.4), 240.0 (100), 227.0 (52.1), 225.0 (23.5), 214.0 (65.6), 207.0 (46.3), 199.0 (39.3), 171,0 (48.4), 143.0 (41.5), 105.0 (41.5), 99.0 (33.1), 77.0 (22.4), 67.0 (25.0), 55.0 (15.9). ${ }^{1} \mathrm{H}-\mathrm{NMR}\left(\mathrm{CD}_{3} \mathrm{COCD}_{3}\right) \delta: 3.80\left(6 \mathrm{H}, \mathrm{s}, 2 \times \mathrm{OCH}_{3}\right), 3.55\left(2 \mathrm{H}, \mathrm{m}, \mathrm{CH}_{2}\right), 3.00(2 \mathrm{H}, \mathrm{t}$, $\left.\mathrm{CH}_{2}\right), 2.18\left(3 \mathrm{H}, \mathrm{s}, \mathrm{CH}_{3}\right)$.

N-Acetyl-S-(2-methly-1,4-naphthoquinonyl-3)cysteine, MQ-(N-Ac)Cys. To a solution of MQ-0 (344 mg, $2.0 \mathrm{mmol}$ ) in a mixture of $12 \mathrm{~mL}$ of ethanol and $2 \mathrm{~mL}$ of water was added N-acetyl Lcysteine (163 mg,1.0 mmol). The solution was stirred overnight and precipitates occurred. The yellow solid was filtered and washed first with water then with ethyl ether, finally dried in vacuo to give MQ(N-Ac)Cys) as a yellow substance (204 mg, yield $61 \%$ ). ESI-MS m/z: $334[\mathrm{M}+\mathrm{H}]^{+}, 356[\mathrm{M}+\mathrm{Na}]^{+}$. EIMS m/z (\%) : 333.2 (3.1), 303 (3.1), 274 (26.8), 229 (23.9), 217 (100), 190 (15.8), 149 (19.2), 115 (37.9), 43 (39.8). ${ }^{1} \mathrm{H}-\mathrm{NMR}\left(\mathrm{DMSO}_{6} \mathrm{~d}_{6}\right) \delta: 8.38(1 \mathrm{H}, \mathrm{d}, \mathrm{NH}), 8.08(2 \mathrm{H}, \mathrm{m}, \mathrm{H}-5,8), 7.92(2 \mathrm{H}, \mathrm{m}, \mathrm{H}-6$, 7), $4.52(1 \mathrm{H}, \mathrm{m}, \mathrm{H}-\alpha), 3.68(1 \mathrm{H}, \mathrm{dd}, \mathrm{H} 1-\beta), 3.48(1 \mathrm{H}, \mathrm{dd}, \mathrm{H} 2-\beta), 2.38\left(3 \mathrm{H}, \mathrm{s}, \mathrm{CH}_{3}\right), 1.79(3 \mathrm{H}, \mathrm{s}$, $\left.\mathrm{CH}_{3} \mathrm{CO}\right)$. These data is consistent with that reported. ${ }^{15}$

S-(2-methly-1,4-naphthoquinonyl-3)-2-mercaptoethanol, $\mathrm{MQ}-\mathrm{S}\left(\mathrm{CH}_{2}\right)_{2} \mathrm{OH}$. To a solution of MQ-0 (212 $\mathrm{mg}, 1.25 \mathrm{mmol}$ ) in $10 \mathrm{~mL}$ of ethanol was added 2-mercaptoethanol (87 $\mu \mathrm{L}, 1.1 \mathrm{mmol}$ ). The solution was stirred overnight. Added $250 \mathrm{mg}$ of $\mathrm{K}_{2} \mathrm{Cr}_{2} \mathrm{O}_{7}$ in $10 \mathrm{~mL}$ of water, stirred for $20 \mathrm{~min}$, then extracted with $3 \times 20 \mathrm{~mL}$ of ethyl ether, washed the solvent with $3 \times 20 \mathrm{~mL}$ of water, evaporated the solvent. The residue was dissolved in mixture of acetonitrile and water and was directly purified by preparative HPLC to yield MQ-S( $\left(\mathrm{CH}_{2}\right)_{2} \mathrm{OH}$ as a yellow substance (130 mg, yield $48 \%$ ). UV-vis, $\lambda_{\max }$ : 259, 328, $421 \mathrm{~nm}$. ESI-MS m/z: $248.6[\mathrm{M}+\mathrm{H}]^{+} .{ }^{1} \mathrm{H}-\mathrm{NMR}$ data is the same as that reported. ${ }^{14 a}$

N-Acetyl-S-(2,3,5-trimethyl-1,4-benzylquinonyl-6)cysteine, TMBQ-(N-Ac)Cys. To a solution of TMBQ (145 mg, $1.0 \mathrm{mmol}$ ) of in a mixture of $2.5 \mathrm{~mL}$ of ethanol and $0.5 \mathrm{~mL}$ of water was added $\mathrm{N}$ acetyl L-cysteine (160 mg, $1.0 \mathrm{mmol}$ ). The solution was stirred overnight. The reaction mixture was purified by preparative HPLC and yielded TMBQ-(N-Ac)Cys as red solid (11 mg, yield $12 \%)$. ESIMS m/z: 312 [M+H] ${ }^{+}$. EI-MS m/z (\%): 313 (0.56), 184 (53.0), 152 (56.3), 137 (34.3), 111 (20.3), 87 (35.7), 43 (100). ${ }^{1} \mathrm{H}-\mathrm{NMR}\left(\mathrm{CD}_{3} \mathrm{COCD}_{3}\right) \delta: 7.38(1 \mathrm{H}, \mathrm{d}, \mathrm{NH}), 4.65(1 \mathrm{H}, \mathrm{m}, \mathrm{H}-\alpha), 3.60(1 \mathrm{H}, \mathrm{dd}, \mathrm{H} 1-$ $\beta$ ), 3.48 (1H, dd, H2- $\beta$ ), 2.12, 2.01, 1.99 (each 3H, s, $\mathrm{CH}_{3}$ ), 1.79 (3H, s, $\mathrm{CH}_{3} \mathrm{CO}$ ).

\section{Reactions of quinones with yeast iso-1 cytochrome $c$.}

Quinones (dissolved in acetonitrile $1.0 \mathrm{mg} / \mathrm{mL}$ ) (all in 20-fold molar excess) were incubated in degassed $50 \mathrm{mM}$ Tris-HCl buffer, $100 \mathrm{mM} \mathrm{NaCl}$, pH 7.5, with cyt $c$ at concentration of $1.0 \mathrm{mg} / \mathrm{mL}$. The solutions were then stirred for 2-6 h at RT under argon in the dark. Quinones were also reacted with cyt $c$ in $0.1 \mathrm{M} \mathrm{NaOAc}$, pH 4.0. Analytical HPLC and subsequent analysis of eluents by ESI-MS were used for monitoring the reactions. Yields of UQ-cyt $c$, MQ-cyt $c$, and TMBQ-cyt $c$ were $50 \%, 30 \%$, and $50 \%$, respectively. Additionally found were disulfide dimer of cyt $c$ (mass found $25414.0 \pm 7$, yield approx. $40 \%$ ) and oxidized cyt $c$ with sulfinic acid $\left(\mathrm{SO}_{2} \mathrm{H}\right)$ (mass found $12738.2 \pm$ 2.2, yiled 10\%). 
A partial reduction of ferric heme to the ferrous form by the generated hydroquinones was monitored for all reactions and is consistent with the positive midpoint redox potential of yeast iso- 1 cyt $c$ of $+290 \mathrm{mV}^{22}$ being $150-290 \mathrm{mV}$ more positive than those of the quinones at $\mathrm{pH}$ 7. This was also found for the reaction of MQ-0 with oxyhemoglobin. ${ }^{9}$ The hydroquinone-protein conjugates was easily converted to the oxidized form by addition of a minimum amount of $\mathrm{K}_{3}\left[\mathrm{Fe}(\mathrm{CN})_{6}\right]$ (Scheme $1 \mathrm{~A}$ ) and subsequent purification by gel filtration (PD-10 column).

\section{Reactions of thioether quinone adducts with yeast iso-1 cytochrome $c$.}

Thioether quinone adducts (dissolved in degassed $50 \mathrm{mM}$ of Tris-HCl buffer, $100 \mathrm{mM} \mathrm{NaCl}$, pH 7.5 at concentration $0.5 \mathrm{mg} / \mathrm{mL}$ ) (all in 10-fold molar excess) was incubated in the same buffer with cyt $c$ at concentration of $1.0 \mathrm{mg} / \mathrm{mL}$. The solutions were then stirred for 2-6 h at RT under argon in the dark. Analytical HPLC and subsequent analysis of eluents by ESI-MS are used for monitoring the reactions.

\section{Cyanogen bromide cleavage of quinone-cyt $c$.}

Typical $0.1 \mathrm{mg}$ of protein was dissolved in $0.1 \mathrm{~mL}$ of $70 \%$ formic acid and mixed with 200 fold excess of cyanogen bromide (CNBr). The mixture was kept in the dark overnight, diluted with $0.5 \mathrm{~mL}$ of water and lyophilized. The lyophilized sample was dissolved in a mixture of acetonitrile and water, and subjected for HPLC analysis and purification with a gradient from $95 \%$ B to $60 \%$ B over 45 min. The fractions containing quinone-peptides eluting at 36-38 min were collected and further lyophilized. The lyophilized samples were subjected to ESI- and PSD-MALDI MS analysis.

\section{UV-visible spectrometry.}

UV-visible spectra of cyt $c$, UQ-cyt $c$, MQ-cyt $c$, and TMBQ-cyt $c$ were recorded in $50 \mathrm{mM}$ Tris-HCl, $100 \mathrm{mM} \mathrm{NaCl}(\mathrm{pH}$ 8.0) with a Varian 100 Cary spectrometer at room temperature.

\section{Cyclic voltammetry.}

Cyclic voltammetry of quinones in acetonitrile was carried out in specially constructed cells containing an internal drying column with highly activated alumina. ${ }^{21}$ The working electrode was a Pt. Disk sealed in soft glass (1.0 mm diameter). A Pt wire, wrapped around the glass of the working electrode, was used as the counter electrode. The reference electrode was an Ag wire on which AgCl had been deposited electrochemically, immersed in the electrolyte solution. Potentials were calibrated with ferrocene $(+0.352 \mathrm{~V}$ vs. Ag/AgCl). The measurements were performed with a Jaissle IMP 88 potentiostat and a PAR 173 programmer. The data were recorded with a computer-assisted transient recorder (Keithley, KPCI 3116). 

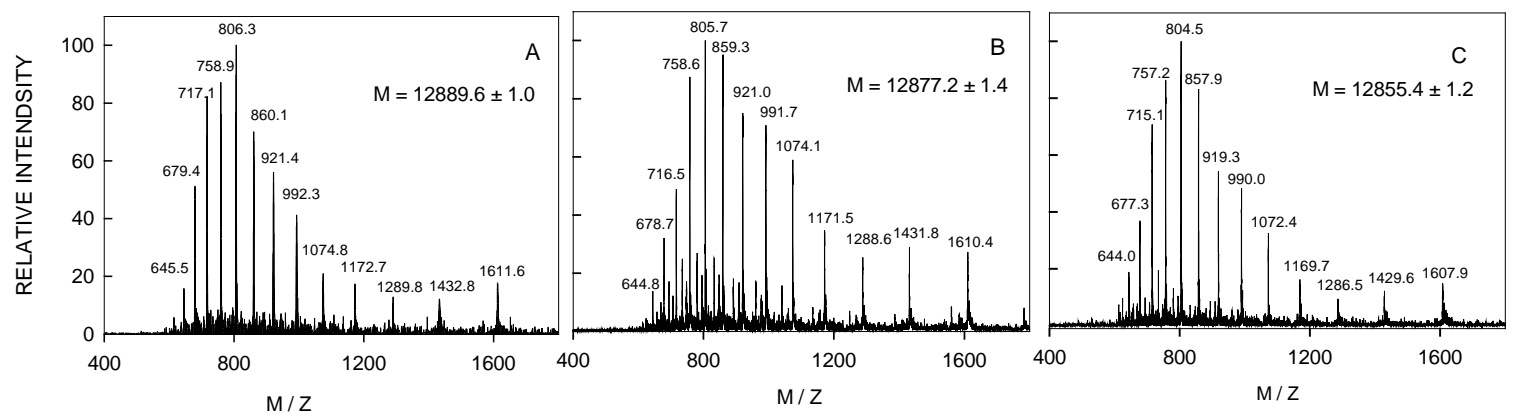

Figure 1s. Electrospray ionization mass spectra of purified UQ-cyt $c$ (A), MQ-cyt $c$ (B) and TMBQcyt $c$ (C). The deconvoluted masses for these quinone thioether cyt $c$ adducts are also shown in Table 1 for comparison with unmodified cyt $c$.
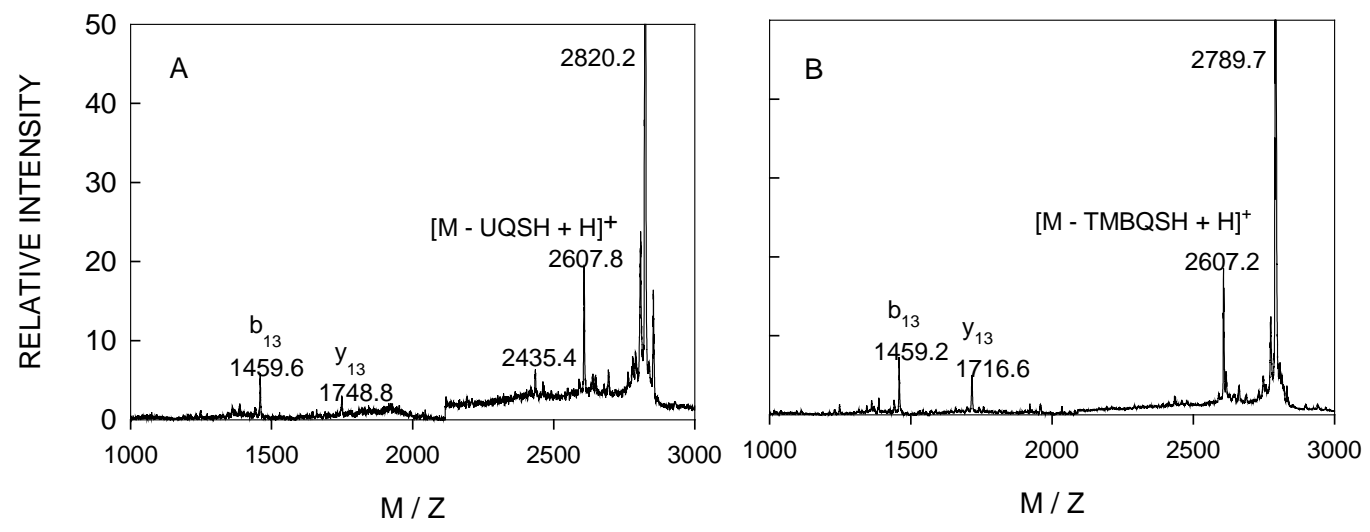

Figure 2s. PSD-MALDI-TOF MS spectra of UQ-peptide 81-103 (A) and TMBQ-peptide 81-103 (B). Two common significant fragmentation ions at $\mathrm{m} / \mathrm{z} 1459$ and 2607 for both of UQ- and TMBQpeptide 81-103 were found to be $B_{13}$ ion and a ion by loss of respective quinone moiety with thiol group via $\beta$-elimination. Different ions at $\mathrm{m} / \mathrm{z} 1749$ and 1717 corresponding to $\mathrm{y}_{13}$ ions contained UQ0 and TMBQ moiety, respectively. Therefore, UQ-0 and TMBQ were confirmed to be located at only Cys-102 as MQ-0.

Table 1s. Masses of cyt $c$, quinone-cyt $c$ conjugates, and quinone-peptide conjugates (cleaved by CNBr) from ESI-MS.

\begin{tabular}{|lcc|}
\hline protein and peptides & calcd. average mass (Da) & found mass (Da) \\
\hline cyt $c$ & 12710.2 & $12712.0 \pm 1.5$ \\
UQ-cyt $c$ & 12890.3 & $12889.6 \pm 1.0$ \\
MQ-cyt $c$ & 12880.3 & $12877.2 \pm 1.4$ \\
TMBQ-cyt $c$ & 12858.3 & $12855.4 \pm 1.2$ \\
peptide 81-103 & 2642.1 & not determined \\
UQ-peptide 86-103 & 2822.2 & $2820.8 \pm 0.4$ \\
MQ-peptide 81-103 & 2812.2 & $2810.6 \pm 0.3$ \\
TMBQ-peptide 81-103 & 2790.2 & $2789.2 \pm 0.4$ \\
\hline
\end{tabular}




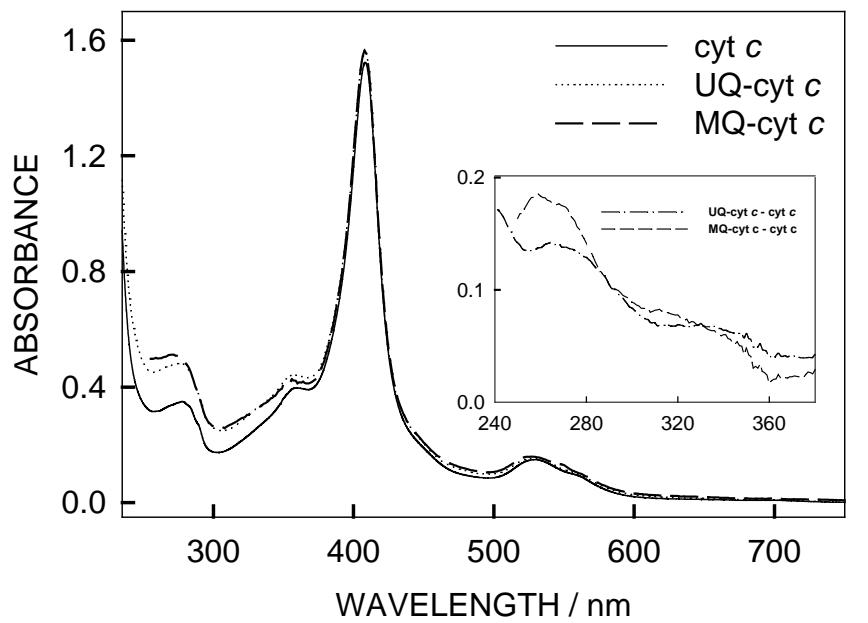

Figure 3s. Normalized UV-visible spectra of cyt $c$, UQ-cyt $c$ and MQ-cyt $c$ in $50 \mathrm{mM}$ Tris-HCl and $100 \mathrm{mM} \mathrm{NaCl}, \mathrm{pH}$ 8.0. UQ-cyt $c$ and MQ-cyt $c$ showed the same maximum absorption at $408 \mathrm{~nm}$ and $530 \mathrm{~nm}$, which are attributed to $\gamma$ - and $\beta$-bands as those of cyt $c$. The significant increase of absorption in the range of 240-380 nm was attributed to the attachment of UQ-0 and MQ-0 to cyt $c$. Their difference spectra between UQ-cyt $c$, MQ-cyt $c$ and cyt $c$ in that range (inset) show the maximum absorption at $268 \mathrm{~nm}$ for the thioether UQ-0 moiety and maximum absorption at $259 \mathrm{~nm}$ for the thioether MQ-0 moiety, which were consistent with those of their model thioether quinones. Again, this demonstrated the binding of quinones to cyt $c$ through thioether bond formation, which supported the results from mass spectrometric analysis. The UV-vis spectrum of TMBQ-cyt c (not shown) displayed a similar feature as that of UQ-cyt $c$.

Table 2s. Maxima of UV-vis spectra of the quinone-cyt $c$ adducts and of their difference to the UV-vis spectrum of cyt $c$ due to the additional absorbance of the bound quinone.

\begin{tabular}{|ll|}
\hline Quinone-cyt $c$ adducts & \multicolumn{1}{c|}{$\lambda_{\max }(\mathrm{nm})$} \\
\hline UQ-cyt $c$ & $278,408,529$. \\
UQ-cyt $c$ minus cyt $c$ & $268,330$. \\
MQ-cyt $c$ & $272,408,529$. \\
MQ-cyt $c$ minus cyt $c$ & $259,320$. \\
TMBQ-cyt $c$ & $269,408,529$. \\
TMBQ-cyt $c$ minus cyt $c$ & $240,264,310$. \\
\hline
\end{tabular}


Table 3s. Electrochemical data for the two one-electron transfers of quinones in acetonitrile.

\begin{tabular}{|lcc|}
\hline Quinones & $\mathrm{E}_{1}{ }^{\circ}(\mathrm{V})$ & $\mathrm{E}_{2}{ }^{\circ}(\mathrm{V})$ \\
\hline UQ-0 & -0.67 & -1.74 \\
UQ-S $\left(\mathrm{CH}_{2}\right)_{2} \mathrm{OH}$ & -0.60 & -1.41 \\
UQ-(N-Ac)Cys & -0.71 & -1.50 \\
MQ-0 & -0.82 & -1.57 \\
MQ-(N-Ac)Cys & -0.84 & -1.61 \\
TMBQ & -0.79 & -1.74 \\
TMBQ-(N-Ac)Cys & -0.80 & -1.81 \\
\hline
\end{tabular}

\section{References}

(1) (a) Trumpower, B. L. eds. Function of quinones in energy conserving systems. 1982, Academic Press, New York. (b) Sies, H.; Packer, L. eds. Methods Enzymol. 2004, Vol. 378 and Vol. 382, Elsevier Academic Press, San Diego, London.

(2) Dove, J. E.; Klinman, J. P. Adv. Protein Chem. 2001, 58, 142-172.

(3) Datta, S.; Mori, Y.; Takagi, K.; Kawaguchi, K.; Chen, Z.; Okajima, T.; Kuroda, S.; Ikeda, T.; Kano, K.; Tanizawa, K.; Mathews, F. S. Proc. Natl. Acad. Sci. U. S. A. 2001, 98, 14268- 14273.

(4) Qi, D.; Tann, C. M.; Haring, D.; Distefano, M. D. Chem. Rev. 2001, 101, 3081-3111.

(5) Alfonta, L.; Zhang, Z.; Uryu, S.; Loo, J. A.; Schultz, P. G. J. Am. Chem. Soc. 2003, 125, 1466214663.

(6) Finley, K. T. in The chemistry of quinonoid compounds; Patai, S.; Rappoport, Z. eds.; John Wiley \& Sons Ltd., New York. 1974, Section I, Chapter 17, 878-1144; 1988, Vol. II, Chapter 11, 538718.

(7) Brunark, A.; Cadenas, E. Free Radic. Biol. Med. 1989, 7, 435-477.

(8) Guo, Q.; Corbett, J. T.; Yue, G-H.; Fann, A. C.; Qian, S.Y.; Tomer, K. B.; Mason, R. P. J. Biol. Chem. 2002, 277, 6104-6110.

(9) Winterbourn, M. C.; French, J. K.; Claridge, R. F. C. Biochem. J. 1979, 179, 665-673.

(10)Malpica, R.; Franco, B.; Rodriguez, C.; Kwon, O.; Georgellis, D. Proc. Natl. Acad. Sci. U. S. A. 2004, 101, 13318-13323.

(11)Santa-Maria, I.; Hernandez, F.; Martin, C. F.; Avila, J.; Moreno, F. J. Biochemistry 2004, 43, 2888-2897.

(12)Scott, R. A. ; Mauk, A. G. eds. Cytochrome c. A multidisplinary approach. 1996, University Science Books, Sausalito, CA.

(13)Louie, G. V.; Brayer, G. D. J. Mol. Biol. 1990, 214, 527-555.

(14)(a) Kerns, J.; Naganathan, S.; Dowd, P.; Finn, F. M.; Carr, B. I. Bioorg. Chem. 1995, 23, 101-109. (b) Kar, S.; Lefterov, I. M.; Wang, M.; Lazo, J. S.; Scott, C. N.; Wilcox, C. S.; Carr, B. I. Biochemistry, 2003, 42, 10490-10497.

(15)Brown, P. C.; Dulick, D. M.; Jone, T. M. Arch. Biochem. Biophys. 1991, 285, 187-196.

(16)Mason, D. E.; Liebler, D. C. Chem. Res. Toxicol. 2000, 13, 976-982.

(17)Gupta, N.; Linschitz, H. J. Am. Chem. Soc. 1997, 119, 6384-6391.

(18)Mauzeroll, J.; Bard, A. J. Proc. Natl. Acad. Sci. U.S.A. 2004, 101, 7862-7867.

(19)Li, W. W.; Carell, T.; Haehnel, W. in Chorev, M.; Sawyr. T. (Eds.) Peptides evolution: genomics, proteomics \& therapeutics (Proceeding of 18th American Peptide Symposium), 2003, 383-384.

(20)Adams, R.; Geissman, T. A.; Baker, B. R.; Teeter, H. M. J. Am. Chem. Soc. 1941, 63, 528-534.

(21)Kiesele, H. Anal. Chem. 1981, 53, 1952-1954.

(22)Lett, C. M.; Guillemette, J. G. Biochem. J. 2002, 362, 281-287. 